
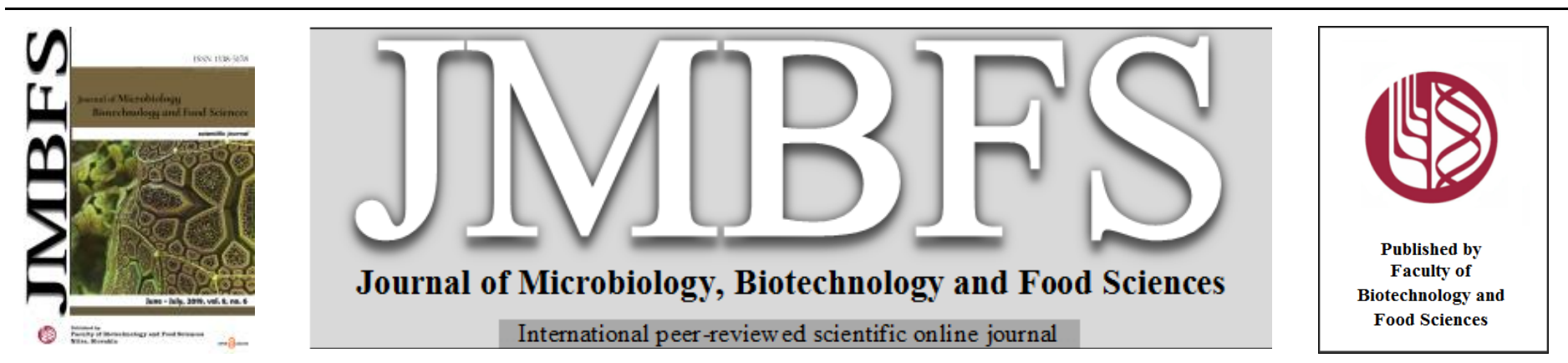

\title{
IN VITRO SCREENING OF ANTIOXIDANT AND ANTIMICROBIAL ACTIVITIES OF MEDICINAL PLANTS GROWING IN SLOVAKIA
}

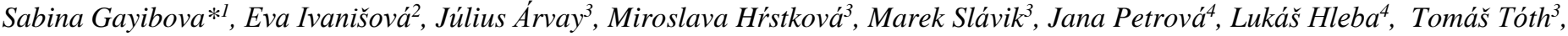 \\ Miroslava Kačániová ${ }^{4}$, Takhir Aripov ${ }^{1}$
}

Address(es): Sabina Gayibova, MSc

${ }^{1}$ Institute of Bioorganic Chemistry, Academy of Sciences of Uzbekistan, Laboratory of Physical and Chemical Methods of Research, Mirzo Ulugbek Str., 83, 100143, Tashkent, Uzbekistan.

${ }^{2}$ Slovak University of Agriculture in Nitra, Department of Storing and Processing of Plant Products, Tr. A. Hlinku 2, 94976, Nitra, Slovakia.

${ }^{3}$ Slovak University of Agriculture in Nitra, Department of Chemistry, Tr. A.Hlinku 2, 949 76, Nitra, Slovakia.

${ }^{4}$ Slovak University of Agriculture in Nitra, Department of Microbiology, Tr. A. Hlinku 2, 949 76, Nitra, Slovakia.

*Corresponding author: gayibova.sabina@gmail.com

doi: 10.15414/jmbfs.2019.8.6.1281-1289

ARTICLE INFO

Received 8. 10. 2018

Revised 29.1.2019

Accepted 29. 1. 2019

Published 1. 6. 2019

Regular article

open 2 access

\begin{abstract}
Traditional medicine usage at the preventive medicine level is comprehensive and plant-based remedies are being prescribed for the treatment of a large scale of diseases by indigenous medical practitioners around the world. The phytochemicals being observed in the fruits and vegetables as well as herbal plants are getting investigated intensively as their important role in the avoidance of diverse human diseases is undoubtful. Antioxidant and antimicrobial activities of selected medicinal herbs were evaluated in this study. Aerial parts of plants from Hypericaceae, Lamiaceae, Fabaceae, Plantaginaceae, Rubiaceae growing wild in Slovakia (locality Zobor) were investigated to characterize their polyphenol content, flavonoid content, as well as antioxidant and antimicrobial activity. Inspection of the metabolic profile combined with HPLC data showed that the ethanol extract contained mainly eight polyphenols with apigenin, daidzein, kaempferol, rutin, quercetin, vitexin, and cynaroside as the main chemicals. Among them, neochlorogenic acid, chlorogenic acid, trans-p-caffeic acid, trans-p-coumaric acid, trans-p-sinapic acid, trans-p-ferulic acid, rosmarinic acid were identified. The antioxidant capacity of ethanol extracts was evaluated by employing DPPH radical scavenging and phosphomolybdenum assays. All samples were also tested against Gram-positive (Staphylococcus aureus, Bacillus thuringiensis, Micrococcus luteus, Staphyloccocus epidermidis) and Gram-negative (Citrobacter koseri, Escherichia coli, Pseudomonas proteolytica, Hafnia alvei, Salmonella enterica, Yersinia enterocolitica) bacterial species using the disk diffusion and minimum inhibitory concentration assays.
\end{abstract}

Keywords: polyphenols, phenolic acids, flavonoids, chemical profile, herbs

\section{INTRODUCTION}

Medicinal plants have been used extensively as alternative agents for the treatment of various infections and diseases for thousands of years (JamshidiKia et al., 2018). Traditional herbs have received much attention as a source of novel drugs since they are considered safe for human use (Yixuan et al., 2007). Plant-based medicines are widely used for primary health care in many developing countries (Abu-Irmaileh et al., 2003). As a result, it is found that about $60-80 \%$ of the world population relies on traditional treatment. The contribution of medicinal plants and natural products as drugs or as sources of using drugs in medicine is unquestionable (WHO, 2002). Numerous secondary metabolites such as alkaloids, tannins, and flavonoids extracted from different medicinal plants have shown antioxidant (Rauf et al., 2013), anticancer (Yizhong et al., 2004; Costa-Lotufo et al., 2005), anti-inflammatory (Latifi et al., 2015), antibacterial potential (Mahboubi et al., 2012).

The Slovak Republic is situated in Central Europe. It is placed in the climatically welcoming mild zone of Northern Hemisphere. Since time traditional medicinal plants have proved their important part in the content of therapeutic and various preparations used in popular human health medicine in Slovak. In past centuries about 600 to 800 species were used for curative reasons (Salamon, 2014). Nowadays about 200 medicinal plants are used in the official therapy and in popular doctoring, respectively (Salamon, 2015). It is approved by the years of positive experience of people carrying explicit contact with nature. Over the years this experience has been validated in practice, improved and categorized, folk herbalist knowledge got formed and passed through generations. This study focused on 7 plants form 5 plant family as useful in traditionally managing various human diseases. We have summarized the data obtained from published literature and the uses of chosen studied plants in folk medicine in Table 1. Infectious diseases are a major cause of death and disability in humans as they prevail constant and rapid change. With microorganisms emerging new preventions and treatments evolve as well. It has been reported that almost $25 \%$ of the population experienced 2-3 episodes of infection every year (Shuman et al., 2018). Many foods primarily deteriorate because of microbes that give rise to the loss of quality and safety, on which people worldwide are concerning more because foodborne diseases are subject to outbreak due to pathogenic and spoilage microorganisms in foods (Rawat, 2015). Moreover, for a long time considered to be non-pathogenic to humans, some bacteria have been sporadically identified as responsible for various infectious diseases in humans. Numerous diseases, even those that were once easily healed, are becoming a huge problem. Noteworthy, the frequency of sporadically infections can also be underestimated. Hence, search for novel antimicrobial compounds or alternative therapy for these resistant infectious agents is inevitable.

Antibacterial compounds provided widely by herbal species may have crucial applications in the nearest future as native antimicrobial components not only in the food industry but also for the medicinal purpose. The antimicrobial activity mechanisms of important herbal species demonstrate the process of bacteria growth inhibition that may involve cytoplasmic membrane destabilization and further excessive permeabilization, extracellular microbial enzymes inhibition, etc. Antimicrobial mechanism of action of herbs may also be connected with antiadherence of bacteria to epithelial cells, being essential means for colonization and infection of many pathogens (Davidson et al., 2015).

In the present study, we used 10 strains of Gram-negative and Gram-positive bacteria, with known and/or recently found pathogenesis against humans and animals. Data summarized in Table 2. 
Table 1 Short summary of traditional medicinal uses of studied plants

\begin{tabular}{|c|c|c|c|c|}
\hline Common name & Botanical name & Family & Use in traditional medicine & References \\
\hline $\begin{array}{l}\text { Yellow } \\
\text { toadflax }\end{array}$ & Linaria vulgaris $L$. & Plantaginaceae & $\begin{array}{l}\text { To treat coughs and asthma. Possesses uterine } \\
\text { stimulatory activity, expectorant, antiseptic, } \\
\text { antiperiodic and anthelminthic properties }\end{array}$ & $\begin{array}{l}\text { (Hua et al., 2002, } \\
\text { Bruhn, 1982) }\end{array}$ \\
\hline $\begin{array}{c}\text { Yellow } \\
\text { bedstraw }\end{array}$ & Galium verum $\mathrm{L}$. & Rubiaceae & $\begin{array}{l}\text { Used as preventive and/or a concomitant } \\
\text { therapeutic approach in head and neck cancer }\end{array}$ & (Schmidt et al., 2013) \\
\hline $\begin{array}{l}\text { Perforate St } \\
\text { John's-wort }\end{array}$ & $\begin{array}{c}\text { Hypericum } \\
\text { perforatum } \mathrm{L} \text {. }\end{array}$ & Hypericaceae & $\begin{array}{l}\text { The popular treatment for anxiety, depression, } \\
\text { cuts, and burns. }\end{array}$ & (Gaster et al., 2000) \\
\hline Black locust & $\begin{array}{c}\text { Robinia } \\
\text { pseudoacacia } \mathrm{L} .\end{array}$ & Fabaceae & $\begin{array}{l}\text { Demonstrates laxative, antispasmodic, diuretic } \\
\text { effect }\end{array}$ & (Subramoniam, 2016) \\
\hline $\begin{array}{l}\text { Hungarian } \\
\text { thyme }\end{array}$ & $\begin{array}{c}\text { Thymus } \\
\text { pannonicus } \mathrm{L} \text {. }\end{array}$ & Lamiaceae & $\begin{array}{l}\text { Popular against coughs and other respiratory } \\
\text { complaints, as well as some cases of } \\
\text { gastrointestinal disorders }\end{array}$ & $\begin{array}{l}\text { (Maksimović et al., } \\
\text { 2008) }\end{array}$ \\
\hline Lemon balm & $\begin{array}{l}\text { Melissa officinalis } \\
\text { L. }\end{array}$ & Lamiaceae & $\begin{array}{l}\text { Menstrual problems, hypertension, migraines, } \\
\text { vertigo and fever, depression and melancholy, } \\
\text { bronchitis and asthma, eczema and gout, } \\
\text { epilepsy, paralysis, Bell's palsy, and } \\
\text { arthritis. Advanced researches showed its } \\
\text { neuroprotective, anxiolytic, antispasmodic, } \\
\text { antihyperlipidemic and hepatoprotective effects. }\end{array}$ & $\begin{array}{l}\text { (Lopez et al., 2009, } \\
\text { Kennedy et al., 2004, } \\
\text { Cases et al., 2011) }\end{array}$ \\
\hline Sage & $\begin{array}{l}\text { Salvia officinalis } \\
\text { L. }\end{array}$ & Lamiacea & $\begin{array}{l}\text { Used in the treatment of digestive and circulation } \\
\text { disturbances, bronchitis, cough, asthma, angina, } \\
\text { mouth and throat inflammations, depression, } \\
\text { excessive sweating, skin diseases, and many } \\
\text { other diseases }\end{array}$ & $\begin{array}{l}\text { (Rami et al., 2011, } \\
\text { Walch et al., 2011, } \\
\text { Khan et al., 2011) }\end{array}$ \\
\hline
\end{tabular}

Table 2 Studied bacteria strains and their reported pathogenic effects

\begin{tabular}{|c|c|c|c|c|}
\hline Bacteria & $\begin{array}{c}\text { Gram } \\
\text { test }\end{array}$ & Family: & Pathogenesis & References \\
\hline $\begin{array}{c}\text { Bacillus } \\
\text { thuringiensis }\end{array}$ & + & Bacillaceae & Nongastrointestinal infections in mammals & $\begin{array}{l}\text { (Celandroni et } \\
\text { al., 2014) }\end{array}$ \\
\hline Micrococcus luteus & + & Micrococcaceae & $\begin{array}{l}\text { Septic arthritis, meningitis, and prosthetic valve } \\
\text { endocarditis }\end{array}$ & $\begin{array}{l}\text { (Miltiadous et al., } \\
\text { 2011) }\end{array}$ \\
\hline $\begin{array}{l}\text { Staphyloccocus } \\
\text { epidermidis }\end{array}$ & + & Staphylococcaceae & $\begin{array}{l}\text { Devastating effects on certain organs such as kidney, } \\
\text { liver, intestine, stomach, and spleen which, depending } \\
\text { on their severity, could be fatal }\end{array}$ & $\begin{array}{l}\text { (Akinkunmi et } \\
\text { al., 2014) }\end{array}$ \\
\hline $\begin{array}{l}\text { Staphyloccocus } \\
\text { aureus }\end{array}$ & + & Staphylococcaceae & $\begin{array}{l}\text { Bacteremia and infective endocarditis as well as } \\
\text { osteoarticular, skin and soft tissue, pleuropulmonary, } \\
\text { and device-related infections. }\end{array}$ & $\begin{array}{lll}\text { (Tong } & \text { et } \\
\text { 2015) } & & \end{array}$ \\
\hline Citrobacter koseri & - & Enterobacteriaceae. & $\begin{array}{l}\text { Neonatal meningitis and brain abscess with high } \\
\text { mortality rates }\end{array}$ & (Lin et al., 2011) \\
\hline Escherichia coli & - & Enterobacteriaceae & $\begin{array}{l}\text { Urinary tract infections, meningitis, pneumonia, } \\
\text { septicemia, and other types of infections }\end{array}$ & $\begin{array}{l}\text { (Russo and } \\
\text { Johnson, 2003, } \\
\text { Smith et al., } \\
\text { 2007, Fratamico, } \\
\text { 2016) }\end{array}$ \\
\hline $\begin{array}{l}\text { Pseudomonas } \\
\text { proteolytica }\end{array}$ & - & Pseudomonadaceae & Not found in the literature & $\begin{array}{l}\text { (Chauhan et al., } \\
\text { 2015) }\end{array}$ \\
\hline Hafnia alvei & - & Enterobacteriaceae & $\begin{array}{l}\text { Gastroenteritis, meningitis, bacteremia, pneumonia, } \\
\text { nosocomial wound infections, endophthalmitis, and a } \\
\text { buttock abscess }\end{array}$ & $\begin{array}{l}\text { (Günthard and } \\
\text { Pennekamp, } \\
\text { 1996) }\end{array}$ \\
\hline Salmonella enterica & - & Enterobacteriaceae & $\begin{array}{l}\text { Gastroenteritis, bacteremia, enteric fever, and an } \\
\text { asymptomatic carrier state }\end{array}$ & $\begin{array}{l}\text { (Ryan and Ray, } \\
\text { 2004) }\end{array}$ \\
\hline $\begin{array}{c}\text { Yersinia } \\
\text { enterocolitica }\end{array}$ & - & Enterobacteriaceae & $\begin{array}{l}\text { Diarrhea in the inoculated animals followed by } \\
\text { lethality in guinea pigs and mice, but negative for } \\
\text { autoagglutination test, calcium dependency, } \\
\text { conjunctivitis, and positive for heat-stable enterotoxin } \\
\text { production }\end{array}$ & $\begin{array}{l}\text { (Igumbor et al., } \\
\text { 1993) }\end{array}$ \\
\hline
\end{tabular}

The aims of the present study were (1) to evaluate total polyphenol, phenolic acid and flavonoid content in ethanolic extract of selected medicinal herbs (2) to assess the antioxidant activity of these samples; (3) to detect the antibacterial activities of samples against gram-positive and gram-negative bacteria.

\section{MATERIAL AND METHODS}

\section{Chemicals and Reagents}

The HPLC phenolic standards were apigenin, daidzein, kaempferol, resveratrol, rutin, quercetin, vitexin, neochlorogenic acid, chlorogenic acid, trans- $p$-caffeic acid, trans- $p$-coumaric acid, trans- $p$-sinapic acid, trans- $p$-ferulic acid, rosmarinic acid. All other chemicals and reagents were of analytical grade and were purchased from Reachem (Slovakia) and Sigma Aldrich (Germany and/or Switzerland). Cynaroside as a standard was kindly provided by Prof. Peter Rapta, DSc (Institute of Physical Chemistry and Chemical Physics, Bratislava, The Slovak Republic).

\section{Plant material}

Mature plant samples were harvested in May 2016 from the spontaneous flora in Slovak Republic (locality Zobor, DMS N $\quad 48^{\circ} 19^{\prime} \quad 46.676$ "E $18^{\circ} 6^{\prime} \quad 2.003 "$ ) and identified. Aerial parts of the collected plants were separated from undesirable materials and dried in open air under shade for 2 weeks. The dried plants were powdered with a mechanical grinder to obtain a coarse powder, stored in an airtight container and kept in a cool, dark, and dry place until analysis commenced.

\section{Preparation of extracts}

Content of selected polyphenolic compounds (apigenin, cynaroside, daidzein, kaempferol, resveratrol, rutin, quercetin, vitexin, neochlorogenic acid, chlorogenic acid, trans-p-caffeic acid, trans-p-coumaric acid, trans-p-sinapic acid, trans- $p$-ferulic acid, rosmarinic acid) was performed by HPLC method (according to Novakova et al. 2010), as described below.

Preparation of calibration solutions: the standard stock solution was prepared by dissolving $0.5 \mathrm{mg}$ each of them with methanol in $10 \mathrm{ml}$ volumetric glass flasks. 
All standard solutions were kept at $6^{\circ} \mathrm{C}$ in the dark for a maximum of $3 \mathrm{~h}$. prior to injection, the solutions were filtered through syringe filter Q-Max $(0.22 \mu \mathrm{m}$; Frisenette ApS, Knebel, Denmark).

Sample preparation: Dried plants $(2.5 \mathrm{~g})$ after homogenization in a mortar were extracted with $25 \mathrm{ml}$ of $80 \%$ ethanol (v/v) at laboratory temperature for $8 \mathrm{~h}$ (Unimax 2010, Heidolph Instrument, Schwabach, Germany). The extract was filtered through Munktell No 390 paper (Munktell \& Filtrac, Barenstein, Germany) and stored in closed $20 \mathrm{ml}$ vial tubes. Prior to injection, the extracts were filtered through syringe filter Q-Max $(0.22 \mu \mathrm{m}$; Frisenette ApS, Knebel, Denmark).

HPLC analyses: The phenolic compounds were analyzed using an Agilent 1260 Infinity high-performance liquid chromatography (Agilent Technologies, Waldbronn, Germany). Separation was achieved on a Purosphere reverse-phase C18 column (4 $\mathrm{mm} \times 250 \mathrm{~mm} \times 5 \mu \mathrm{m})$ Merck KGaA, Darmstadt, Germany). The solvents were: (A) acetic acid in methanol (50/1000ml), (B) acetic acid in HPLC grade water $(50 / 1000 \mathrm{ml})$. the following gradient program was employed: $0-5 \mathrm{~min}$ isocratic elution $(20 \% \mathrm{~A}$ and $80 \% \mathrm{~B}), 5-11$ min linear gradient elution $(60 \% \mathrm{~A}$ and $40 \% \mathrm{~B}$ ), and $80 \% \mathrm{~A}$ and $20 \% \mathrm{~B} 11-20 \mathrm{~min}$. the initial flow rate was 1 $\mathrm{ml} / \mathrm{min}$. column oven temperature was set up to $30^{\circ} \mathrm{C}$ and the samples were kep at $4{ }^{\circ} \mathrm{C}$ in the sample manner. The PDA detection was conducted at $330 \mathrm{~nm}$ for quantitative purposes with data acquisition rate of $5 \mathrm{~Hz}$. Detection was carried out in a diode array detector (DAD), within 210-400 $\mathrm{nm}$ as the preferred wavelengths.

\section{Radical scavenging activity}

Radical scavenging activity of extracts was measured using 2,2-diphenyl-1picrylhydrazyl (DPPH) (Sanchéz-Moreno et al., 1998). The sample $(0.4 \mathrm{ml})$ was mixed with $3.6 \mathrm{ml}$ of DPPH solution (0.025 g DPPH in $100 \mathrm{ml}$ methanol). An absorbance of the reaction mixture was determined using the spectrophotometer Jenway (6405 UV/Vis, England) at $515 \mathrm{~nm}$. Trolox (6-hydroxy-2,5,7,8 tetramethylchroman-2carboxylic acid) $\left(10-100 \mathrm{mg} / \mathrm{L} ; R^{2}=0.989\right)$ was used as the standard and the results were expressed in $\mathrm{mg} / \mathrm{g}$ Trolox equivalents.

\section{Reducing power}

Reducing power of extracts was determined by the phosphomolybdenum method of Prieto et al. (1999) with slight modifications. The mixture of sample $(1 \mathrm{ml})$, monopotassium phosphate $(2.8 \mathrm{ml}, 0.1 \mathrm{M})$, sulfuric acid $(6 \mathrm{ml}, 1 \mathrm{M})$, ammonium heptamolybdate $(0.4 \mathrm{ml}, 0.1 \mathrm{M})$ and distilled water $(0.8 \mathrm{ml})$ was incubated at $90^{\circ} \mathrm{C}$ for $120 \mathrm{~min}$, then rapidly cooled and detected by monitoring absorbance at $700 \mathrm{~nm}$ using the spectrophotometer Jenway (6405 UV/Vis, England). Trolox $\left(10-1000 \mathrm{mg} / \mathrm{L} ; R^{2}=0.998\right)$ was used as the standard and the results were expressed in $\mathrm{mg} / \mathrm{g}$ Trolox equivalents.

\section{Total polyphenol content}

Total polyphenol content of extracts was measured by the method of Singleton and Rossi (1965) using Folin-Ciocalteu reagent. $0.1 \mathrm{ml}$ of each sample was mixed with $0.1 \mathrm{ml}$ of the Folin-Ciocalteu reagent, $1 \mathrm{ml}$ of $20 \%$ (w/v) sodium carbonate, and $8.8 \mathrm{ml}$ of distilled water. After $30 \mathrm{~min}$. in darkness the absorbance at $700 \mathrm{~nm}$ was measured using the spectrophotometer Jenway $(6405 \mathrm{UV} / \mathrm{V}$ is, England). Gallic acid $\left(25-300 \mathrm{mg} / \mathrm{L} ; R^{2}=0.998\right)$ was used as the standard and the results were expressed in $\mathrm{mg} / \mathrm{g}$ gallic acid equivalents (mg GAE/g).

\section{Total flavonoid content}

Total flavonoids were determined using the modified method of Willett (2002) $0.5 \mathrm{ml}$ of sample was mixed with $0.1 \mathrm{ml}$ of $10 \%(\mathrm{w} / \mathrm{v})$ ethanolic solution of aluminium chloride, $0.1 \mathrm{ml}$ of $1 \mathrm{M}$ potassium acetate and $4.3 \mathrm{ml}$ of distilled water. After $30 \mathrm{~min}$. in darkness the absorbance at $415 \mathrm{~nm}$ was measured using the spectrophotometer Jenway (6405 UV/Vis, England). Quercetin $(0.520 \mathrm{mg} / \mathrm{L}$; $\left.R^{2}=0.989\right)$ was used as the standard and the results were expressed in $\mu \mathrm{g} / \mathrm{g}$ quercetin equivalents (mg QE/g).

\section{Total phenolic acid content}

Total phenolic acids content was determined using the method of Farmakopea Polska (1999). A $0.5 \mathrm{~mL}$ of sample extract was mixed with $0.5 \mathrm{~mL}$ of $0.5 \mathrm{M}$ hydrochloric acid, $0.5 \mathrm{~mL}$ Arnova reagent $\left(10 \% \mathrm{NaNO}_{2}+10 \% \mathrm{Na}_{2} \mathrm{MoO}_{4}\right), 0.5$ $\mathrm{mL}$ of $1 \mathrm{M}$ sodium hydroxide (w/v) and $0.5 \mathrm{~mL}$ of water. Absorbance at $490 \mathrm{~nm}$ was measured using the spectrophotometer Jenway (6405 UV/Vis, England). Caffeic acid (1-200 mg. $\left.\mathrm{L}^{-1}, R^{2}=0.9996\right)$ was used as a standard and the results were expressed in $\mathrm{mg} / \mathrm{g}$ caffeic acid equivalents $(\mathrm{mg} \mathrm{CAE} / \mathrm{g}$ )

\section{Microbial strains}

Ten strains of microorganisms were tested in this study, Gram-negative bacteria: Escherichia coli CCM 3988, Salmonella enterica subsp. enterica CCM 3807 Yersinia enterocolitica CCM 5671, Citrobacter koseri CCM 2535, Pseudomonas proteolytica CCM 7690, Hafnia alvei CCM 2636 and Gram-positive bacteria: Bacillus thuringiensis CCM 19 ${ }^{\mathrm{T}}$, Stapylococcus aureus subsp. aureus CCM 2461, Micrococcus luteus CCM 732, Staphylococcus epidermidis CCM 4684. Al tested strains were collected from the Czech Collection of microorganisms. The bacterial suspensions were cultured in the nutrient broth (Imuna, Slovakia) at $37^{\circ} \mathrm{C}$

\section{Disc diffusion method}

Antimicrobial activity of each plant extract was determined by a disc diffusion method. Briefly, $100 \mu \mathrm{l}$ of the test bacteria were grown in $10 \mathrm{ml}$ of fresh media until they reached a count of approximately 10E5 colony-forming units $(\mathrm{cfu}) / \mathrm{ml}$. Then $100 \mu \mathrm{l}$ of the microbial suspension was spread onto Mueller Hinton agar plates. The extracts were tested using $6 \mathrm{~mm}$ sterilized filter paper discs. The diameters of the inhibition zones were measured in millimetres. All measurements were to the closest whole millimetre. Each antimicrobial assay was performed in at least triplicate. Filter discs impregnated with $10 \mu \mathrm{l}$ of distilled water were used as a negative control.

\section{Microbroth dilution method}

MICs were determined by the microbroth dilution method according to the Clinical and Laboratory Standards Institute recommendation (CLSI, 2015) in Mueller Hinton broth (Biolife, Italy). Briefly, the DMSO plant extracts solutions were prepared as serial two-fold dilutions obtaining a final concentration ranging between $0.5-512 \mu \mathrm{g} / \mathrm{ml}$. After that, each well was inoculated with the microbial suspension at the final density of 0.5 McFarland. After $24 \mathrm{~h}$ of incubation at $37^{\circ} \mathrm{C}$, the inhibition of microbial growth was evaluated by measuring the well absorbance at $450 \mathrm{~nm}$ in an absorbance microplate reader Biotek EL808 with a shaker (Biotek Instruments, USA). The 96 microwell plates were measured before and after an experiment. Differences between both measurements were evaluated as growth. Measurement error was established for 0.05 values of absorbance. Wells without plant extracts were used as negative controls of growth. Pure DMSO was used as negative control. This experiment was done in eight-replicates for a higher accuracy of the MICs of used medical plant extracts.

\section{Statistical analysis}

All experimental measurements were carried out in triplicate and are expressed as an average of three analyses \pm standard deviation. The correlations coefficient $\left(\mathrm{R}^{2}\right)$ between the parameters established by regression analysis.

\section{RESULTS AND DISCUSSION}

\section{Total polyphenolic, flavonoids and phenolic acids content}

Total polyphenolic content, total flavonoid content and total phenolic acids content of the seven extracts considered in this study are presented in Table 3. Total polyphenolic content under the applied conditions varied from $60,94 \pm 6.68$ (L.vulgaris) to $10.05 \pm 0.17$ (R.pseudoacacia) $\mathrm{mg}$ GAE per $\mathrm{g}$ of sample. According to the Table 3, the polyphenolic content of 3 species from Lamiaceae family (M.officinalis, S.officinalis, and T.pannonicus) were quite similar (20.90 \pm $1.06,20.01 \pm 0.71$ and $23.98 \pm 1.37 \mathrm{mg}$ GAE per $\mathrm{g}$ of sample respectively).

The flavonoid content of studied extracts varied from $83.72 \pm 1.29$ (L.vulgaris) to $11.56 \pm 0.15$ (R.pseudoacacia) $\mathrm{mg}$ QE per $\mathrm{g}$ of sample. The flavonoid contents of species from Lamiaceae family varied lightly but all were less than $20 \mathrm{mg}$ QE per $\mathrm{g}$ of sample - M.officinalis (11.56 \pm 0.15$)$, S.officinalis $(14,35 \pm 0.49)$ and T.pannonicus. $(19,35 \pm 1.22) \mathrm{mg}$ QE per $\mathrm{g}$ of sample.

The total phenolic acids content of the studied ethanolic extracts varied within the samples, from $2.50 \pm 0.74$ (R.pseudoacacia) to $52.25 \pm 2.61$ (L.vulgaris) $\mathrm{mg}$ CAE per gram of sample. Lamiaceae family species namely lemon balm, sage and thyme had the values $(24.24 \pm 2.80,18.52 \pm 7,73$ and $16.74 \pm 7.56 \mathrm{mg}$ CAE per gram of sample) respectively.

In general, L.vulgaris and H.perforatum had the highest content of polyphenols, flavonoids, and phenolic acids while R.pseudoacacia had the lowest.

\section{Antiradical and antioxidant activity}

DPPH is a widely used free radical for simple and fast estimation of the antiradical capacity due to its stability, reliability and the simplicity of the assay (Ali, 2013). DPPH radical scavenging capacity of ethanolic extracts is presented in Table 4.

The total antioxidant assay based on the reduction of phosphate-molybdenum (VI) to phosphate-molybdenum (V) gives the information on the presence of antioxidant components in the sample predicting the antioxidant activity of crude extracts on the total basis. The total antioxidant activity of ethanolic extracts was evaluated, and the results were expressed as mg Trolox equivalents/g (Table 4). 
Table 3 Total polyphenolic, flavonoids and phenolic acids content of studied samples

\begin{tabular}{|cccc|} 
Ethanolic extracts & $\begin{array}{c}\text { Total } \\
\text { polyphenolic } \\
\text { content } \mathbf{( m g} \\
\text { GAE/g) }\end{array}$ & $\begin{array}{c}\text { Total } \\
\text { flavonoid } \\
\text { content } \\
\text { (mg QE/g) }\end{array}$ & $\begin{array}{c}\text { Total phenolic } \\
\text { acids content } \\
\text { (mg CAE/g) }\end{array}$ \\
\hline Linaria vulgaris L. & $60.94 \pm 6.68$ & $83.72 \pm 1.29$ & $52.25 \pm 2.61$ \\
\hline Galium verum L. & $37.53 \pm 1.90$ & $48.83 \pm 0.81$ & $29.41 \pm 4.84$ \\
\hline Thymus pannonicus $L$. & $23.98 \pm 1.37$ & $19.35 \pm 1.22$ & $16.74 \pm 7.56$ \\
\hline $\begin{array}{c}\text { Hypericum perforatum } \\
\text { L. }\end{array}$ & $50.79 \pm 2.02$ & $72.40 \pm 2.45$ & $46.06 \pm 7.26$ \\
\hline $\begin{array}{c}\text { Robinia pseudoacacia } \\
\text { L. }\end{array}$ & $10.05 \pm 0.17$ & $15.27 \pm 0.97$ & $2.50 \pm 0.74$ \\
\hline Melissa officinalis L. & $20.90 \pm 1.06$ & $11.56 \pm 0.15$ & $24.24 \pm 2.80$ \\
\hline Salvia officinalis L. & $20.01 \pm 0.71$ & $14.35 \pm 0.49$ & $18.52 \pm 7.73$ \\
\hline
\end{tabular}

GAE - gallic acid equivalent; QE - quercetin equivalent; CAE -caffeic acid equivalent; mean \pm standard deviation

Table 4 DPPH scavenging effect vs total antioxidant capacity of studied ethanolic extracts. Values are expressed as mean \pm standard deviation $(n=3)$, the correlation between total antioxidant capacity and total antiradical activity $\mathrm{R}^{2}=$ 0.23 .

\begin{tabular}{|ccc|}
\hline Ethanolic extracts & $\begin{array}{c}\text { Reducing power } \\
(\mathbf{m g} \text { TEAC/g) }\end{array}$ & $\begin{array}{c}\text { Radical scavenging } \\
\text { activity }(\mathbf{m g} \text { TEAC/g) }\end{array}$ \\
\hline Linaria vulgaris $L$. & $8.38 \pm 0.08$ & $134.49 \pm 3.63$ \\
\hline Galium verum $L$. & $8.00 \pm 0.46$ & $63.61 \pm 7.62$ \\
\hline Thymus pannonicus $L$. & $8.23 \pm 0.19$ & $52.71 \pm 4.08$ \\
\hline Hypericum perforatum $L$. & $8.56 \pm 0.07$ & $135.47 \pm 42.21$ \\
\hline Robinia pseudoacacia $L$. & $3.96 \pm 0.40$ & $17.92 \pm 3.36$ \\
\hline Melissa officinalis $L$. & $8.99 \pm 0.04$ & $51.43 \pm 4.46$ \\
\hline Salvia officinalis $L$. & $8.96 \pm 0.04$ & $48.08 \pm 2.07$ \\
\hline
\end{tabular}

TEAC - Trolox equivalent antioxidant capacity; mean \pm standard deviation
Table 5 the correlation between antioxidant and antiradical capacity and phenolic, phenolic acids and flavonoid contents of studied ethanolic extracts

\begin{tabular}{|ccc|}
\hline Ethanolic extracts & $\begin{array}{c}\text { Reducing power } \\
(\text { mg TEAC/g) }\end{array}$ & $\begin{array}{c}\text { Radical scavenging } \\
\text { activity }(\mathbf{m g} \\
\text { TEAC/g) }\end{array}$ \\
\hline $\begin{array}{c}\text { total phenolic content }(\mathrm{mg} \\
\text { GAE/g) }\end{array}$ & $\mathrm{R}^{2}=0.92$ & $\mathrm{R}^{2}=0.34$ \\
\hline $\begin{array}{c}\text { total flavonoid content }(\mathrm{mg} \\
\text { QE/g) }\end{array}$ & $\mathrm{R}^{2}=0.86$ & $\mathrm{R}^{2}=0.05$ \\
\hline $\begin{array}{c}\text { total phenolic acids content }(\mathrm{mg} \\
\text { CAE/g) }\end{array}$ & $\mathrm{R}^{2}=0.93$ & $\mathrm{R}^{2}=0,19$ \\
\hline
\end{tabular}

GAE - gallic acid equivalent; QE - quercetin equivalent; CAE -caffeic acid equivalent; TEAC - Trolox equivalent antioxidant capacity

The total flavonoid, polyphenol and phenolic acids content correlated with the phosphomolybdenum assay ( $\mathrm{R} 2=0.86,0.92$ and 0.93 , respectively). The results suggested that the phenolic compounds contributed significantly to the antioxidant capacity of the medicinal herbs. However, a direct correlation between radical scavenging activity and total flavonoid, polyphenolic, and phenolic acids contents failed to demonstrate linear regression.

\section{Quantification of polyphenolic compounds by HPLC}

Targeted metabolic profiling of studied ethanolic extracts using HPLC has resulted in the characterization of seven phenolic acids namely neochlorogenic acid, chlorogenic acid, trans-caffeic acid, trans-p-coumaric acid, trans-p-sinapic acid, trans-p-ferulic acid and rosmarinic acid and eight flavonoids namely apigenin, cynaroside, daidzein, kaempferol, rutin, quercetin and vitexin in various quantities (Table 6)

Of them, cynaroside, neochlorogenic and trans-p-coumaric acid were found in all the samples. Resveratrol was not observed in any extracts.

The persistent presence of cynaroside was observed in all the strains and the maximum content was $1434.14 \pm 2.40$ in extracts of G.verum followed by $1385.55 \pm 1.57$ in T.pannonicus and $1360.19 \pm 1.51$ in R.pseudoacacia. $\backslash$ L.vulgaris sample contained the least amount of cynaroside (55.36 \pm 0.49$)$ in comparison to its content in other samples.

The correlation between the antioxidant, antiradical activities and total polyphenolic, phenolic acids and flavonoid contents of the studied medicinal plants ethanolic extracts were calculated (Table 5).

Table 6 The content of standard samples in mg per kg of the total dry extracts or the dry plant material. Values are expressed as mean \pm standard deviation $(n=3)$

\begin{tabular}{|c|c|c|c|c|c|c|c|}
\hline Extract & $\begin{array}{c}\text { Linaria } \\
\text { vulgaris L. }\end{array}$ & $\begin{array}{c}\text { Galium } \\
\text { verum } \mathrm{L} .\end{array}$ & $\begin{array}{c}\text { Thymus } \\
\text { pannonicus } \\
\text { L. }\end{array}$ & $\begin{array}{c}\text { Hypericum } \\
\text { perforatum } \\
\text { L. }\end{array}$ & $\begin{array}{c}\text { Robinia } \\
\text { pseudoacacia } \\
\text { L. }\end{array}$ & $\begin{array}{c}\text { Salvia } \\
\text { officinalis } \mathbf{L} .\end{array}$ & $\begin{array}{c}\text { Melissa } \\
\text { officinalis L. }\end{array}$ \\
\hline Apigenin & $\begin{array}{c}5.06 \\
\pm 0.03 \\
\end{array}$ & - & - & - & - & $\begin{array}{l}58.00 \\
\pm 5.47 \\
\end{array}$ & $\begin{array}{l}41.71 \\
\pm 20.6 \\
\end{array}$ \\
\hline Cynaroside & $\begin{array}{l}55.36 \\
\pm 0.49 \\
\end{array}$ & $\begin{array}{c}1434.14 \\
\pm 2.40 \\
\end{array}$ & $\begin{array}{c}1385.55 \\
\pm 1.57 \\
\end{array}$ & $\begin{array}{l}429.25 \\
\pm 0.57 \\
\end{array}$ & $\begin{array}{c}1360.19 \\
\pm 1.51 \\
\end{array}$ & $\begin{array}{c}567.97 \\
\pm 19.4 \\
\end{array}$ & $\begin{array}{c}408.13 \\
\pm 30.0\end{array}$ \\
\hline Daidzein & $\begin{array}{l}24.28 \\
\pm 0.47 \\
\end{array}$ & $\begin{array}{l}15.30 \\
\pm 0.02 \\
\end{array}$ & - & - & - & - & $\begin{array}{l}51.25 \\
\pm 8.07 \\
\end{array}$ \\
\hline Kaempferol & - & - & - & $\begin{array}{l}15.54 \\
\pm 0.19\end{array}$ & - & $\begin{array}{l}43.89 \\
\pm 2.20\end{array}$ & - \\
\hline Resveratrol & - & - & - & - & - & - & - \\
\hline Rutin & $\begin{array}{l}220.06 \\
\pm 17.13\end{array}$ & $\begin{array}{l}491.93 \\
\pm 1.65\end{array}$ & $\begin{array}{l}27.06 \\
\pm 3.83\end{array}$ & $\begin{array}{l}176.41 \\
\pm 0.44\end{array}$ & $\begin{array}{l}23.63 \\
\pm 0.57\end{array}$ & $\begin{array}{l}130.68 \\
\pm 6.63\end{array}$ & - \\
\hline Quercetin & - & $\begin{array}{c}4.69 \\
\pm 0.16\end{array}$ & $\begin{array}{l}139.56 \\
\pm 0.48\end{array}$ & $\begin{array}{c}4.84 \\
\pm 0.06\end{array}$ & $\begin{array}{l}39.50 \\
\pm 0.04\end{array}$ & $\begin{array}{l}24.50 \\
\pm 0.66\end{array}$ & - \\
\hline Vitexin & - & $\begin{array}{c}8.14 \\
\pm 3.32\end{array}$ & - & - & $\begin{array}{l}26.77 \\
\pm 0.15\end{array}$ & $\begin{array}{l}64.85 \\
\pm 3.24\end{array}$ & - \\
\hline $\begin{array}{c}\text { Neochlorogenic } \\
\text { acid }\end{array}$ & $\begin{array}{c}138.09 \\
\pm 8.19\end{array}$ & $\begin{array}{l}228.15 \\
\pm 6.35\end{array}$ & $\begin{array}{l}316.36 \\
\pm 9.65\end{array}$ & $\begin{array}{l}179.11 \\
\pm 9.79\end{array}$ & $\begin{array}{l}612.98 \\
\pm 0.71\end{array}$ & $\begin{array}{l}136.44 \\
\pm 4.11\end{array}$ & $\begin{array}{l}113.14 \\
\pm 8.07\end{array}$ \\
\hline $\begin{array}{l}\text { Chlorogenic } \\
\text { acid }\end{array}$ & $\begin{array}{c}1010.07 \\
\pm 8.81\end{array}$ & $\begin{array}{l}2886.92 \\
\pm 11.82\end{array}$ & $\begin{array}{l}698.99 \\
\pm 0.32\end{array}$ & - & $\begin{array}{l}677.95 \\
\pm 0.98\end{array}$ & - & - \\
\hline $\begin{array}{c}\text { Trans-p-caffeic } \\
\text { acid }\end{array}$ & - & - & $\begin{array}{c}2.17 \\
\pm 0.05\end{array}$ & $\begin{array}{l}7.73 \\
\pm 0.06\end{array}$ & $\begin{array}{l}11.76 \\
\pm 0.07\end{array}$ & $\begin{array}{l}472.0 .5 \\
\pm 62.5\end{array}$ & $\begin{array}{l}220.15 \\
\pm 5.88\end{array}$ \\
\hline $\begin{array}{c}\text { Trans-p- } \\
\text { coumaric acid }\end{array}$ & $\begin{array}{c}0.14 \\
\pm 0.06\end{array}$ & $\begin{array}{c}3.79 \\
\pm 0.03 \\
\end{array}$ & $\begin{array}{c}0.08 \\
\pm 0.02\end{array}$ & $\begin{array}{c}1.69 \\
\pm 0.02 \\
\end{array}$ & $\begin{array}{c}1.34 \\
\pm 0.04\end{array}$ & $\begin{array}{l}285.62 \\
\pm 4.58 \\
\end{array}$ & $\begin{array}{l}13.37 \\
\pm 2.84\end{array}$ \\
\hline $\begin{array}{c}\text { Trans-p-sinapic } \\
\text { acid }\end{array}$ & $\begin{array}{l}110.91 \\
\pm 0.09\end{array}$ & $\begin{array}{c}9.01 \\
\pm 0.03\end{array}$ & $\begin{array}{c}2.58 \\
\pm 0.01\end{array}$ & $\begin{array}{l}15.13 \\
\pm 0.08\end{array}$ & $\begin{array}{c}3.69 \\
\pm 0.09\end{array}$ & - & - \\
\hline $\begin{array}{c}\text { Trans-p-ferulic } \\
\text { acid }\end{array}$ & - & $\begin{array}{l}12.10 \\
\pm 0.05\end{array}$ & $\begin{array}{l}39.84 \\
\pm 0.04\end{array}$ & $\begin{array}{l}86.34 \\
\pm 0.05\end{array}$ & $\begin{array}{l}36.98 \\
\pm 0.15\end{array}$ & $\begin{array}{l}24.68 \\
\pm 2.70\end{array}$ & - \\
\hline $\begin{array}{l}\text { Rosmarinic } \\
\text { acid }\end{array}$ & $\begin{array}{l}184.34 \\
\pm 1.07\end{array}$ & $\begin{array}{l}196.02 \\
\pm 0.55\end{array}$ & - & $\begin{array}{l}13.38 \\
\pm 0.17\end{array}$ & - & $\begin{array}{c}2906.73 \\
\pm 150\end{array}$ & $\begin{array}{l}6914.1 \\
\pm 779\end{array}$ \\
\hline
\end{tabular}


The content of neochlorogenic acid varied from minimum (113.14 \pm 8.07$)$ in M.officinalis. to maximum (612.98 \pm 0.71$)$ in R.pseudoacacia.

The minimum content of trans-p-coumaric acid was as low as $0.08 \pm 0.02$ in T.pannonicus and $0.14 \pm 0.06$ in L.vulgaris. More significant contribution of the phenolic acid was in Salvia officinalis Mill. (285.62 \pm 4.58$)$.

Rutin was found in all the extracts except M.officinalis. The content was as high as $491.93 \pm 1.65$ (in G.verum) and $220.06 \pm 17.13$ (in L.vulgaris), an as low as $27.06 \pm 3.83$ in T.pannonicus and $23.63 \pm 0.57$ in R.pseudoacacia.

S.officinalis and M.officinalis contained the highest content of rosmarinic acid $2906.73 \pm 150$ and $6914.1 \pm 779$ correspondingly.

The maximum content of chlorogenic acid $(2886.92 \pm 11.82)$ was found in G.verum, trans-p-caffeic acid (472.0.5 \pm 62.5$)$ in S.officinalis, trans-p-sinapic acid $(110.91 \pm 0.09)$ in L.vulgaris, trans-p-ferulic acid $(86.34 \pm 0.05)$ in H.perforatum. Among other polyphenols, the presence of quercetin was detected in various quantities in 5 strains, apigenin, daidzein and vitexin in 3 strains, and kaempferol in 2 strains.

\section{Antimicrobial activity}

The serial microdilution results were analyzed using the Analysis of Variance (ANOVA). Single factor statistical tool indicated that there is a significant difference in the sensitivity of the tested microorganisms to the various extracts. The $\mathrm{MIC}_{50}$ ranged from 1.33 to 204.80 , MIC $_{90}$ from $2.92 \mu \mathrm{g} / \mathrm{mL}$ to $304.16 \mu \mathrm{g} / \mathrm{mL}$
(Table 7). The inhibition zone was as high as $12 \mathrm{~mm}$ (by G.verum against Yersinia enterocolitica CCM 5671). In general, there was not observed remarkable correlation between MICs and the inhibition zone parameters. Grampositive bacteria seemed to be more resistant to all the extracts that gramnegative strains - $\mathrm{MIC}_{50}$ was not lower than $25.58 \mu \mathrm{g} / \mathrm{mL}$ and $\mathrm{MIC}_{90}$ was not lower than $27.20 \mu \mathrm{g} / \mathrm{mL}$

Among them Yersinia enterocolitica CCM 5671 was the most succeptible, it was inhibited by G.verum with $\mathrm{MIC}_{50}(1.33 \mu \mathrm{g} / \mathrm{mL})$ and $\mathrm{MIC}_{90}(2.92 \mu \mathrm{g} / \mathrm{mL})$ and the highest inhibitory zone $(12.80 \mathrm{~mm})$. S.officinalis had a bit higher MICs $(5.44$ $\mu \mathrm{g} / \mathrm{mL}$ and $8.59 \mu \mathrm{g} / \mathrm{mL}$ correspondingly), followed by T.pannonicus and H.perforatum $\left(\mathrm{MIC}_{50}=12.80 \mu \mathrm{g} / \mathrm{mL}, \mathrm{MIC}_{90}=13.64 \mu \mathrm{g} / \mathrm{mL}\right)$.

Ps.proteolytica was also effectively inhibited by G.verum, T.pannonicus and H.perforatum $\left(\mathrm{MIC}_{50}=0.80 \mu \mathrm{g} / \mathrm{mL}, 12.80 \mu \mathrm{g} / \mathrm{mL}, 12.80 \mu \mathrm{g} / \mathrm{mL}\right.$ and $\mathrm{MIC}_{90}=$ $0.86 \mu \mathrm{g} / \mathrm{mL}, 13.64 \mu \mathrm{g} / \mathrm{mL}, 13.64 \mu \mathrm{g} / \mathrm{mL}$ ) recpectively. Among Gram -negative bacteria H.alvei was the most succeptible to S.officinalis $\left(\mathrm{MIC}_{50}=10.09 \mu \mathrm{g} / \mathrm{mL}\right.$, $\mathrm{MIC}_{90}=28.00 \mu \mathrm{g} / \mathrm{mL}$ ).

Gram-positive species were less affected by studied extracts. Stapylococcus aureus subsp. aureus CCM 2461 showed succeptibility to H.perforatum $\left(\mathrm{MIC}_{50}=\right.$ $12.80 \mu \mathrm{g} / \mathrm{mL}, \mathrm{MIC}_{90}=13.64 \mu \mathrm{g} / \mathrm{mL}$ ). In general, the microorganisms of the species Ps.proteolityca and Yersinia enterocolitica CCM 5671 were the most susceptible to most plant extracts tested in this work (with MICs $<25 \mu \mathrm{g} / \mathrm{mL}$ )

Table 7 The antimicrobial activity of medical plant extracts expressed in MICs $(\mu \mathrm{g} / \mathrm{mL})$ and inhibition zones $(\mathrm{mm})$

\begin{tabular}{|c|c|c|c|c|c|c|c|c|}
\hline Microorganism & $\begin{array}{l}\text { Extracts } \\
\text { effect }\end{array}$ & $\begin{array}{l}\text { Linaria } \\
\text { vulgaris } \\
\quad \text { L. }\end{array}$ & $\begin{array}{l}\text { Galium } \\
\text { verum } \\
\text { L. }\end{array}$ & $\begin{array}{c}\text { Thymus } \\
\text { pannonicus } \\
\text { L. }\end{array}$ & $\begin{array}{l}\text { Hypericum } \\
\text { perforatum } \\
\text { L. }\end{array}$ & $\begin{array}{c}\text { Robinia } \\
\text { pseudoacacia } \\
\text { L. }\end{array}$ & $\begin{array}{l}\text { Salvia } \\
\text { officinalis } \\
\text { L. }\end{array}$ & $\begin{array}{l}\text { Melissa } \\
\text { officinalis } \\
\text { L. }\end{array}$ \\
\hline \multirow{3}{*}{$\begin{array}{c}\text { Bacillus } \\
\text { thuringiensis } \\
\text { CCM 19 }^{\mathrm{T}}\end{array}$} & Zone (mm) & $\begin{array}{c}3,67 \\
\pm 0,58\end{array}$ & $\begin{array}{c}4,00 \\
\pm 0,01\end{array}$ & $\begin{array}{c}3,00 \\
\pm 0,01\end{array}$ & $\begin{array}{c}9,00 \\
\pm 0,01\end{array}$ & $\begin{array}{c}1,00 \\
\pm 0,01\end{array}$ & $\begin{array}{c}4,50 \\
\pm 0.40\end{array}$ & $\begin{array}{c}0,50 \\
\pm 0,01\end{array}$ \\
\hline & Mic50 & 102.4 & 25,58 & 51,07 & 25,58 & 25,58 & 144.24 & 158.02 \\
\hline & Mic90 & 102,4 & 27,20 & 54,30 & 27,20 & 27,20 & 232.55 & 304.16 \\
\hline \multirow{3}{*}{$\begin{array}{l}\text { Micrococcus luteus } \\
\text { CCM } 732\end{array}$} & Zone (mm) & $\begin{array}{c}8,00 \\
\pm 0,01 \\
\end{array}$ & $\begin{array}{l}11,00 \\
\pm 0,01\end{array}$ & $\begin{array}{c}4,33 \\
\pm 1,15 \\
\end{array}$ & $\begin{array}{c}5,00 \\
\pm 1,73 \\
\end{array}$ & $\begin{array}{c}1,00 \\
\pm 0,01 \\
\end{array}$ & $\begin{array}{c}1,33 \\
\pm 1,44 \\
\end{array}$ & $\begin{array}{c}0,17 \\
\pm 0,29\end{array}$ \\
\hline & Mic50 & 102,4 & 25,58 & 25,58 & 25,58 & 25,58 & 102.40 & 76.73 \\
\hline & Mic90 & 102,4 & 27,20 & 27,20 & 27,20 & 27,20 & 114.30 & 81.59 \\
\hline \multirow{3}{*}{$\begin{array}{c}\text { Staphylococcus } \\
\text { epidermidis CCM } \\
4684\end{array}$} & Zone & $\begin{array}{c}3,00 \\
\pm 0,01\end{array}$ & $\begin{array}{c}1,00 \\
\pm 0,01\end{array}$ & $\begin{array}{c}4,67 \\
\pm 0,58\end{array}$ & $\begin{array}{c}4,67 \\
\pm 0,58\end{array}$ & $\begin{array}{c}2,33 \\
\pm 0,58\end{array}$ & $\begin{array}{c}0,50 \\
\pm 0,01\end{array}$ & $\begin{array}{c}0,50 \\
\pm 0,01\end{array}$ \\
\hline & Mic50 & 102,4 & 25,58 & 25,58 & 25,58 & 25,58 & 51.20 & 173.79 \\
\hline & Mic90 & 102,4 & 27,20 & 27,20 & 27,20 & 27,20 & 57.24 & 265.97 \\
\hline \multirow{3}{*}{$\begin{array}{l}\text { Stapylococcus aureus } \\
\text { subsp. aureus } \\
\text { CCM } 2461\end{array}$} & Zone & $\begin{array}{c}2,00 \\
\pm 0,01\end{array}$ & $\begin{array}{c}6,00 \\
\pm 0,01\end{array}$ & $\begin{array}{c}1,67 \\
\pm 0,58\end{array}$ & $\begin{array}{c}3,00 \\
\pm 0,01\end{array}$ & $\begin{array}{c}1,00 \\
\pm 0,01\end{array}$ & $\begin{array}{c}0,17 \\
\pm 0,29\end{array}$ & $\begin{array}{c}1,00 \\
\pm 0,50\end{array}$ \\
\hline & Mic50 & 102,4 & 25,58 & 73,80 & 12,80 & 25,58 & 120.06 & 144.24 \\
\hline & Mic90 & 102,4 & 27,20 & 123,73 & 13,64 & 27,20 & 186.06 & 232.55 \\
\hline \multirow{3}{*}{$\begin{array}{l}\text { Citrobacter koseri } \\
\quad \text { CCM } 2535\end{array}$} & Zone & $\begin{array}{c}2,00 \\
\pm 0,01\end{array}$ & $\begin{array}{l}11,00 \\
\pm 0,01\end{array}$ & $\begin{array}{c}2,00 \\
\pm 0,01\end{array}$ & $\begin{array}{c}6,00 \\
\pm 0,01\end{array}$ & $\begin{array}{c}1,00 \\
\pm 0,01\end{array}$ & $\begin{array}{c}1,33 \\
\pm 1,44\end{array}$ & $\begin{array}{c}0,50 \\
\pm 0,01\end{array}$ \\
\hline & Mic50 & 102,4 & 25,58 & 25,58 & 25,58 & 25,58 & 38.88 & 102.40 \\
\hline & Mic90 & 102,4 & 27,20 & 27,20 & 27,20 & 27,20 & 67.51 & 114.3 \\
\hline \multirow{3}{*}{$\begin{array}{c}\text { Escherichia coli } \\
\text { CCM } 3988\end{array}$} & Zone & $\begin{array}{c}1,00 \\
\pm 0,01\end{array}$ & $\begin{array}{c}5,00 \\
\pm 0,01\end{array}$ & $\begin{array}{c}2,00 \\
\pm 0,01\end{array}$ & $\begin{array}{c}3,33 \\
\pm 0,58\end{array}$ & $\begin{array}{c}0,67 \\
\pm 0,58\end{array}$ & $\begin{array}{c}0,00 \\
\pm 0,01\end{array}$ & $\begin{array}{c}0,83 \\
\pm 1,04\end{array}$ \\
\hline & Mic50 & 102,4 & 25,58 & 25,58 & 25,58 & 25,58 & 76.73 & 156.28 \\
\hline & Mic90 & 102,4 & 27,20 & 27,20 & 27,20 & 27,20 & 81.59 & 265.44 \\
\hline \multirow{3}{*}{$\begin{array}{c}\text { Pseudomonas } \\
\text { proteolytica CCM } \\
7690\end{array}$} & Zone & $\begin{array}{c}1,67 \\
\pm 0,58\end{array}$ & $\begin{array}{c}3,00 \\
\pm 0,01\end{array}$ & $\begin{array}{c}2,00 \\
\pm 0,01\end{array}$ & $\begin{array}{c}3,00 \\
\pm 0,01\end{array}$ & $\begin{array}{c}6,00 \\
\pm 0,01\end{array}$ & $\begin{array}{c}4,67 \\
\pm 0,58\end{array}$ & $\begin{array}{c}6,00 \\
\pm 1,00\end{array}$ \\
\hline & Mic50 & 25,57 & 0,80 & 12,80 & 12,80 & 22,74 & 51.20 & 42.96 \\
\hline & Mic90 & 27,20 & 0,86 & 13,64 & 13,64 & 43,90 & 57.24 & 190.83 \\
\hline \multirow{3}{*}{$\begin{array}{c}\text { Hafnia alvei CCM } \\
2636\end{array}$} & Zone & $\begin{array}{c}2,33 \\
\pm 0,58\end{array}$ & $\begin{array}{c}1,00 \\
\pm 0,01\end{array}$ & $\begin{array}{c}1,00 \\
\pm 0,01\end{array}$ & $\begin{array}{c}6,00 \\
\pm 0,01\end{array}$ & $\begin{array}{c}0,00 \\
\pm 0,01\end{array}$ & $\begin{array}{c}1,00 \\
\pm 0,01\end{array}$ & $\begin{array}{c}5,00 \\
\pm 0,01\end{array}$ \\
\hline & Mic50 & 60,25 & 25,57 & 46,18 & 25,57 & 11,32 & 60.04 & 10.09 \\
\hline & Mic90 & 118,72 & 27,20 & 87,68 & 27,20 & 102,4 & 93.49 & 28.00 \\
\hline \multirow{3}{*}{$\begin{array}{l}\text { Salmonella enterica } \\
\text { subsp. } \text { enterica } \\
\text { CCM } 3807\end{array}$} & Zone & $\begin{array}{c}1,00 \\
\pm 0,00\end{array}$ & $\begin{array}{c}1,00 \\
\pm 0,00\end{array}$ & $\begin{array}{c}1,00 \\
\pm 0,00\end{array}$ & $\begin{array}{c}1,00 \\
\pm 0,00\end{array}$ & $\begin{array}{c}1,00 \\
\pm 0,00\end{array}$ & $\begin{array}{c}0,00 \\
\pm 0,00\end{array}$ & $\begin{array}{c}2,17 \\
\pm 3,33\end{array}$ \\
\hline & Mic50 & 102,4 & 25,58 & 25,58 & 25,58 & 25,58 & 51.20 & 204.80 \\
\hline & Mic90 & 102,4 & 27,20 & 27,20 & 27,20 & 27,20 & 57.24 & 228.59 \\
\hline \multirow{3}{*}{$\begin{array}{c}\text { Yersinia } \\
\text { enterocolitica } \\
\text { CCM } 5671\end{array}$} & Zone & $\begin{array}{c}2,00 \\
\pm 0,01\end{array}$ & $\begin{array}{l}12,00 \\
\pm 0,01\end{array}$ & $\begin{array}{c}1,67 \\
\pm 0,58\end{array}$ & $\begin{array}{c}6,00 \\
\pm 0,01\end{array}$ & $\begin{array}{c}1,00 \\
\pm 0,01\end{array}$ & $\begin{array}{c}1,33 \\
\pm 0,58\end{array}$ & $\begin{array}{c}5,00 \\
\pm 0,01\end{array}$ \\
\hline & Mic50 & 102.4 & 1.33 & 12.80 & 12.80 & 25.58 & 45.51 & 5.44 \\
\hline & Mic90 & 102.4 & 2.92 & 13.64 & 13.64 & 27.20 & 85.74 & 8.59 \\
\hline
\end{tabular}

It has been reported that the wild plants are the most abundant and cheapest source of food for the human community and they are also used for the medicinal purpose as a source of antioxidant compounds. Antioxidants like phenolic acids, polyphenols, and flavonoids scavenge free radicals inhibiting the oxidative stress 
that leads to a number of human diseases (asthma, inflammatory arthropathies, diabetes, Parkinson's and Alzheimer's diseases, cancers as well as atherosclerosis). Due to Armatu et al. (2010) low content of polyphenols proves a weak or no antioxidant activity and vice versa. Moreover there is no universa rule for expressing the antiradical and antioxidant capacity so they are reported either as $\mathrm{IC}_{50}$ (the antioxidant concentration required to reduce the DPPH absorbance by half), \% loss or original absorbance or Trolox/ascorbic acid equivalent (e.g. mg TEAC/100 g FW, mg/g TE, etc). The latter is just a number for comparison, the former at least considers some concentration dependence. On one hand, this incompatibility makes it difficult to compare the results on the other hand however indirect comparison enables to determine the health benefits and public health relevance of polyphenols promising future for the powerful antioxidants and those who consume them.

DPPH and power reducing assays were used in our work to evaluate the antiradical and antioxidant activity of ethanolic plant extracts. In agreement with other authors the results varied depending on the test applied.

The antioxidant and antiradical activities of Linaria vulgaris were studied were poorly. Thus, Vrchovska et al. (2008) have investigated the ability of $L$. vulgaris lyophilized infusion to act as a scavenger of 2,2-diphenyl-1-picrylhydrazyl (DPPH) radical, reactive oxygen species (superoxide radical, hydroxyl radical, hypochlorous acid) and nitric oxide and proposed the potent antioxidant activity present in the infusion to be ascribed by flavonoid derivatives. Our results show that among other extracts L.vulgaris demonstrated comparatively high antioxidant and antiradical activity.

G.verum samples collected at the flowering period at various parts of Europe, and the extracts prepared in ethanol at different temperatures and different time of extraction exhibit very potent antioxidant activities. Our findings of the antiradical ability of G.verum's ethanolic extract are in agreement with those reported by Lakič et al. (2010), Vlase et al. (2014), Al-Snafi (2018). In addition Lakič et al. (2010) observed quite high scavenging ability of G.verum ethanolic extract against hydroxyl radical and hydrogen peroxide, as well as potency to inhibit lipid peroxidation.

Different antioxidant assays were utilized to evaluate free radical scavenging activity and antioxidant activity of Hypericum perforatum $L$. The plant was reported to be an effective scavenger in quenching DPPH and superoxide radical;, metal-chelating capacity was proposed to attribute to its antioxidant mechanisms (Zou et al., 2004). Mašković et al. (2011) report that the ethanolic extract of $H$. perforatum (from central Serbia) possesses higher antioxidant activity in comparison to the H.perforatum acetonic extract, as well as to such standards as ascorbic acid and butylated hydroxytoluene (BHT). In our work, $S t$ John's-wort ethanolic extract showed very high antiradical activity while the total antioxidant assay based on the reduction of Phosphate-Molybdenum (VI) to Phosphate-Molybdenum (V) showed a low presence of antioxidant component in the extract. In addition, Radulovic et al. (2007) showed that the antioxidan capacity of $H$. perforatum methanolic extract was highest in the case of the flowers (in comparison to leaves and stems) and also was the highest with the comparison to eight other local (South Serbia) Hypericum species.

According to literature Black Locust possesses a very good melliferous potential (class IV-VI): it represents an excellent source of nectar for honey production (Persano-Oddo et al., 2004). Furthermore, this plant's wood is widely used in the wine industry as it was found to increase antioxidant activity of media and is a very effective means of enriching wines and other beverages in functional phytochemicals. The researches show that at higher concentrations $(0.016$ $\mathrm{mg} / \mathrm{mL}$ ), the values of antioxidant activity for ethyl acetate fractions of heartwood and bark of $R$. pseudoacacia from Iran were very close to those observed for very important physiological antioxidant - vitamin C while leaves had the lowest (Hosseinihashemi et al., 2016). On the other hand, Marinas et al. (2014) compared the 70\% ethanol extracts obtained from Robinia pseudoacacia's leaves, seeds and sheaths. The highest content of polyphenols was found in the leaf extract followed by seed extract. Sheath extract showed the lowest content of polyphenols. In accordance with polyphenolic content leaf extracts also showed the strongest antioxidant capacity. On the contrary, our work shows that ethanolic extract of flowers of $R$. pseudoacacia contains a very little amount of polyphenols, phenolic acids and flavonoids $(10,05 \pm 0,17 \mathrm{mg} \mathrm{QE} / \mathrm{g})$ and shows the lowest antioxidant and antiradical capacity compared to other studied plants.

All Lamiaceae family plants possess high amounts of polyphenols, high antioxidant, and antiradical activities. The three studied species, namely $S$. officinalis, M.cofficinalis, and T.pannonicus, confirmed the good antioxidant and antiradical potential of the Lamiaceae species exhibiting almost similar records for radical scavenging $(48.08 \pm 2.07,51.43 \pm 4.46$ and $52.71 \pm 4.08 \mathrm{mg} / \mathrm{g}$ Trolox equivalent, correspondingly) and antioxidant $(8.96 \pm 0.04,8.99 \pm 0.04$ and $8.23 \pm 0.19$ /g Trolox equivalent, correspondingly) capacities probably due to a similar quantity of polyphenols, flavonoids and phenolic acids,

Also, HPLC fingerprints of the extracts were analysed in order to determine phenolic compounds from plant material.

Cheriet et al. (2015) reviewed the data on different Linaria species including the data published as early as 1907 (Klobb, 1907), and the phytochemical content of Linaria species was revised very carefully.. In addition to a long list of flavonoids that have already been detected, we have found some other compounds not mentioned before, that are apigenin, cynaroside (luteolin-7-O- glucoside), daidzein and rutin. Quercetin was also found in agree with Pethes $e t$ al. (1974). Vitexin seemed to be not typical to Linaria species as it was not mentioned to be observed as Linaria species constituent and was also not detected in our experiments. Some other polyphenols reported in the bibliography were identified by reversed-phase HPLC analysis as protocatechuic acid, gallic acid, $p$-hydroxybenzoic acid, vanillic acid and salicylic acid, caffeic acid, $p$ coumaric acid, ferulic acid, homoprotocatechuic acid, $O$-hydroxyphenylacetic acid, gluco-syringic acid and $p$-methoxybenzoic acid (Cheriet $\boldsymbol{e}$ t al., 2015). We were the first to detect also rosmarinic, sinapic and chlorogenic and neochlorogenic acids in $L$. vulgaris ethanolic extract. On the other hand, ferulic and caffeic acids were not detected in contrast to works by SokolowskaWozniak et al. (2003).

In recent years, the consumption of products derived from Hypericum perforatum L., the plant being one of the most popular of medicinal plants worldwide, has increased dramatically,. H.perforatum-derived products are available as phytopharmaceuticals, nutraceuticals, teas, tinctures, juices, and oily macerates (Gaedcke, 2003). The constituents of St John's wort (Hypericum perforatum L.), compiled from several sources (Barnes et al., 2001, Ganzera et al., 2002, Rusalep et al., 2016), may let us consider hyperforin (a prenylated phloroglucinol) and hypericin (a naphthodianthrone) to be the major active constituents of the plant. Besides them, H.perforatum contains additional biologically active compounds such as rutin, quercetin, and chlorogenic acid (Hans, 1998). The chromatographic analysis of H.perforatum extracts also confirmed the presence of kaempferol, luteolin, quercitrin glycosides (hyperoside, quercitrin, and rutoside) (Stuart, 2014). In addition to the abovementioned constutuents, we also observed cynaroside (luteolin-7-O-glycoside) Some amount of phenolic acids such as neochlorogenic and trans-p-ferulic acids were detected, rosmarinic, trans-p-sinapic, trans-p-coumaric and trans-p-caffeic acids were detected in minority.

HPLC analysis of $70 \%$ ethanolic extracts of $R$. pseudoacacia revealed the presence of catechin, rutin, resveratrol and quercetin in the leaf extract, and catechin, epicatechin and rutin in the seed extract; None of these compounds were identified in the sheath extract. (Marinas et al., 2014). In flowers extract we detected rutin and quercetin, as well as a quite high amount of cynaroside and traces of vitexin which were not mentioned to be present in Black locust before. Resveratrol, however, was not detected. For the first time, the presence of chlorogenic and neochlorogenic acids was detected, as well as a little amount of trans-p-ferulic, trans-p-caffeic, trans-p-sinapic and trans-p-coumaric acids.

Lamiaceae species are ones of the oldest and still the most popular medicinal plants. Although previous studies also reported chemical constituents of the extracts investigated herein, the results presented now may show novel aspects of the plants' composition. Thus S.officinalis and M.officinalis were not reported to contain sinapic acid which is in correspondence with other researches (Hernandez-Saavedra et al., 2015). Furthermore, Roby et al. (2013) showed the chemical profile of S.officinalis from Shambolia farm located at Fayoum area in Egypt to contain $p$-coumaric, caffeic, ferulic and rosmarinic acids. M.officinalis was also reported to contain caffeic, ferulic, chlorogenic, rosmarinic acids, the latter being the major constituent (Arceusz and Wesolowski, 2013). On the contrary, chlorogenic acid s was not observed in our samples. The analysis of published literature proves that the presence of neochlorogenic acids observed in S.officinalis and M.officinalis seems to be reported for the first time by us (Zheng and Wang, 2001). On the other hand we showed that another species of Lamiaceae family - Thymus pannonicus - had the highest amount of sinapic acid after Linaria vulgaris. Rosmarinic acid naturally occurring in plants of the Lamiaceae family had the highest content in sage and lemon balm while not being observed in thyme. Contrarily, Boros et al. (2010) showed that $T$. pannonicus grown and sampled at Soroksár, Hungary showed the highest content of rosmarinic acid than other phenolic acids.

There is renewed interest in antimicrobial activities of herbal plants as potential source of polyphenols reported to be effective antimicrobial substances against a wide variety of microorganisms. Seven species from five popular medicinal herbs were tested against Gram-positive and Gram-negative bacteria in terms of the size of inhibition zone $(\mathrm{mm})$, MIC50 $(\mu \mathrm{g} / \mathrm{mL})$ and MIC90 $(\mu \mathrm{g} / \mathrm{mL})$.

In our work $L$. vulgaris ethanolic extract did not show any significant effect against neither Gram-positive nor Gram-negative bacteria. Publications screening did not reveal data on L.vulgaris antimicrobial studies. However the biological study on antibacterial activity was reported to be observed for Linaria corifolia, endemic to Irano-Turanian region (Gonuz et al., 2005). Assuming inhibitory zone assay they showed that the ethanolic extracts of aerial parts of the plant were more effective against Gram-positive bacteria (especially St. epedermidis ATCC 12228 and St.aureus ATCC 6538P) in comparison to Gram-negative bacteria. On the other hand, Gul et al. (2017) reported that ethanolic crude extract of L.corifolia aerial parts was only effective against B.cereus as well as yeast Candida albicans while ethanolic extracts of undersoil parts had an antimicrobial effect against St.aureus.

Antibacterial studies of Galium verum was not reported to possess very strong antibacterial activity against both Gram-positive and Gram-negative bacteria However, it is likely that the nature of solvent might play important role in antimicrobial properties of G.verum. Thus Vlase et al. (2014) compared antimicrobial properties of four ethanolic (70\%) extracts of Galium. Their results 
show that the antimicrobial activity of G.verum was lower than the effect of G.odoratum or G.mollugo. However, G.verum demonstrated some activity against Gram-negative bacteria (S.typhimurium, E.coli) and a moderate antibacterial activity against Gram-positive L.monocytogenes and St.aureus. Extract of G. verum in our work was based on $80 \%$ ethanol and possessed significant activity against Y.enterocolitica with broad inhibition zone and low MICs. High inhibition zone was also observed for M.luteus and C.koseri, and there were very low MICs for Ps.proteolitica. In addition to other works, Galium verum extract (in $96 \%$ ethanol) exhibited high activity in relation to Proteus vulgaris, Pseudomonas aeruginosa, Bacillus subtilis (Shynkovenko et al., 2017) Furthermore in Ilyina et al. (2016) work lipophilic (chloroform) extract of $G$ verum showed a significant level of antimicrobial activity. It has given the basis for a further search of antimicrobial substances among chloroform complexes obtained from different species. Summarizing our results and bibliography G.verum displays more efficiency in reference to Gram-negative microorganisms and slightly less efficiency in reference to Gram-positive strains.

A number of studies are available in the literature regarding in vitro antibacteria activity of Hypericum perforatum and the extracts are reported to be more active than decoctions (Kolesnikova, 1986). The aerial parts of $H$. perforatum are reported to exhibit more pronounced activity against Gram-positive bacteria than Gram-negative bacteria (Reichling et al., 2001, Avato et al., 2004). The antibacterial activity of ethanolic extract of H.perforatum tested in our work showed variations in activity against tested strains. Ps.proteolytica and $Y$. enterocolytica were more susceptible with terms of MICs among Gram-positive bacteria, B.thuringiensis had the highest inhibition zone, and St.aureus had a moderate susceptibility. According to the review by Saddiqe et al. (2010), St.John's wort's antibacterial effect varied significantly depending on solvents, proposing that organic solvents were more suitable for extracting antibacterial plant components. Thus the water extract was active only against S.oxford while petroleum ether, chloroform, and methanolic extracts had high MICs and were active against on P.aeruginosa, S.aureus, S.oxford, S.mutans, S.sanguis, E.coli, P.vulgaris. On the other hand, even $30 \%$ ethanol solution (Lasik et al., 2007) evaluated antagonistic properties against four bacteria - Enterococcus faecium, Bifidobacterium animalis, Lactobacillus plantarum and E.coli isolated from the human large intestine.

Literature data reports the antibacterial effect of aqueous extracts (in contrary to methanol) of black locust flowers against P.putida, B. subtilis, E.coli, S.cerevisiae and P.myxofaciens (Cioch et al., 2017). In additionMarinas et al. (2014) showed that the alcoholic extract of the $R$. pseudoacacia leaves potentiated the antimicrobial activity against the nine tested bacterial strains of E.coli, K. pneumoniae, B.subtilis, S.aureus, and P.aeruginosa while seeds and sheaths extract possessed very poor effect. Oppositely, the studied flower alcoholic extract did not evaluate any significant antimicrobial effect against test strains. Acetone extract from S.officinalis was active against St.aureus, E.coli, P.aeruginosa, B.subtilis, E.cloacae, K.pneumoniae, Pr.mirabilis. St.aureu strains were found to be the most sensitive bacteria to aqueous ethanolic and aqueous methanolic sage extracts (Kozlowska et al., 2015). The distinct antibacterial activity of aqueous ethanolic and aqueous methanolic extracts of S.officinalis was also observed against S.epidermidis and B.bronchiseptica with a MIC value of $0.5 \mathrm{mg} / \mathrm{mL}$, and B.subtilis and G.stearothermophilis with MIC value of $0.25 \mathrm{mg} / \mathrm{mL}$. Recently, the antimicrobial activity of S.officinalis was shown against vancomycin-resistant enterococci (Horiuchi et al., 2007). On the contrary, our work did not show any significant antibacterial effect of sage.

Ehsani et al. (2017) revealed a significant antimicrobial effect of M.officinalis against S.typhimorium, E.coli, L.monocytogenes and S.aureus. According to ou results, the M.officinalis ethanolic extract possesses moderate antibacteria activity against gram-negative Ps.proteolyticca, H.alvei, and Y.enterocolitica. Our results, however, are not supported by some other works like Rabbani $\boldsymbol{e t}$ al. (2015) showing that lemon balm extract had significant antibacterial activity against Gram-positive bacteria such as S. aureus and St. epidermidis.

The previous researches have shown that most aspects of thyme medicinal applications are related to the various levels of thymol and/or carvacrol, phenolic derivatives with strong and wide-spectrum of antimicrobial activity (Maksimović et al., 2008, Nabavi et al., 2014). Though the publications on a crude extract of T.pannonicus are scarce, the works on its volatile oils' antimicrobial activity revealed noteworthy antimicrobial potential against bacteria and yeasts. Our work, however, showed that among all the studied plants T.pannonicus had the highest antibacterial effect against Ps.proteolitica and Y.enterocolitica with regard to inhibition zone that correlated well with MICs.

\section{CONCLUSION}

We have examined the antioxidant, antiradical and antimicrobial activities for seven plant ethanolic extracts and the results complete the lack of literature data with new information concerning the polyphenolic compounds and their bioactivity. Our data demonstrate the difference in antioxidant activities of the reference antioxidants and selected phenolic and flavonoid compounds in different assays. This may be due to the fact that the different antioxidant capacity determining methods have different specificities for different solvents reagents, $\mathrm{pH}$ conditions, or hydrophilic and hydrophobic substances. There seems to be no rule as to the variation of the antioxidant capacity, with the activity also being dependent on the identity of the species and also the site and date of collection. The observed antimicrobial activity confirms evidence of the effectiveness of the traditional use of these herbs drug against various pathogens. In general, the differences in the antiradical, antioxidant and antimicrobial activities may be due to different geographical environment, an age of the plant, the different method followed for isolation, cultivar type, seasonality, etc. Furthermore, the extracts are very complex mixtures of many variable compounds with distinct activities. So we believe that carefully designed studies to standardize methods of extraction and in vitro testing would be advantageous so that the search could be more systematic and interpretation of results would be facilitated.

Acknowledgments: This research was supported Erasmus Mundus project, CASIA III. The authors thank Prof. Peter Rapta (Slovak University of Technology in Bratislava) for kindly provided cynaroside standard.

\section{REFERENCES}

Abu-Irmaileh, B. E., \& Afifi, F. U. (2003). Herbal medicine in Jordan with special emphasis on commonly used herbs. Journal of Ethnopharmacology, 89(23), 193-197. http://doi.org/10.1016/s0378-8741(03)00283-6

Akinkunmi, E. O., Adeyemi, O. I., Igbeneghu, O. A., Olaniyan, E. O., Omonisi, A. E., \& Lamikanra, A. (2014). The pathogenicity of Staphylococcus epidermidis on the intestinal organs of rats and mice: An experimental investigation. BMC Gastroenterology, 14(1). http://doi.org/10.1186/1471-230x-14-126

Ali, M. H., Salem, M. Z. M., \& Al Sahli, A. (2013). Performance of antioxidant activity of methanolic extracts from different parts of some tree species using DPPH radical-scavenging assay. Journal of Pure and Applied Microbiology, 7 131-137.

Al-Snafi, A. (2018). Galium verum - a review. IAJPS, 05 (04), 2142-214910. http://doi.org/10.5281/zenodo.1214980

Arceusz, A., \& Wesolowski, M. (2013). Quality consistency evaluation of Melissa officinalis L. commercial herbs by HPLC fingerprint and quantitation of selected phenolic acids. Journal of Pharmaceutical and Biomedical Analysis, 83, 215-220. http://doi.org/10.1016/j.jpba.2013.05.020

Armatu, A., Mihul, A., Bubueanu, C., Draghici, E. \& Pirvu, L. (2009) Evaluation of antioxidant and free scavenging potential of some Lamiaceae species growing in Romania. Romanian Biotechnological Letters, 15(3), 5274 5280.

Avato, P., Raffo, F., Guglielmi, G., Vitali, C., \& Rosato, A. (2004). Extracts from St Johns wort and their antimicrobial activity. Phytotherapy Research, 18(3), 230-232. http://doi.org/10.1002/ptr.1430

Barnes, J., Anderson, L. A., Phillipson, J. D. (2001). St John's wort (Hypericum perforatum $L$.): a review of its chemistry, pharmacology and clinical properties. J. Pharm. Pharmacol., 53(5), 583-600.

Boros, B., Jakabová, S., Dörnyei, Á, Horváth, G., Pluhár, Z., Kilár, F., \& Felinger, A. (2010). Determination of polyphenolic compounds by liquid chromatography-mass spectrometry in Thymus species. Journal of $\begin{array}{llll}\text { Chromatography } & \text { A, 1217(51), 7972-7980. }\end{array}$ http://doi.org/10.1016/j.chroma.2010.07.042

Bruhn, J. G. (1982). Chemistry and pharmacology of vasicine - A new oxytocic and abortifacient. Journal of Ethnopharmacology, 6(1), 125-126 http://doi.org/10.1016/0378-8741(82)90081-2

Cai, Y., Luo, Q., Sun, M., \& Corke, H. (2004). Antioxidant activity and phenolic compounds of 112 traditional Chinese medicinal plants associated with $\begin{array}{llll}\text { anticancer. } & \text { Life } & \text { Sciences, } & \text { 74(17), }\end{array}$ http://doi.org/10.1016/j.1fs.2003.09.047

Cases, J., Ibarra, A., Feuillère, N., Roller, M., \& Sukkar, S. G. (2010). Pilot trial of Melissa officinalis L. leaf extract in the treatment of volunteers suffering from mild-to-moderate anxiety disorders and sleep disturbances. Mediterranean Journal of Nutrition and Metabolism, 4(3), 211-218. http://doi.org/10.1007/s12349-010-0045-4

Celandroni, F., Salvetti, S., Senesi, S., \& Ghelardi, E. (2014). Bacillus thuringiensis membrane-damaging toxins acting on mammalian cells. FEMS Microbiology Letters, 361(2), 95-103. http://doi.org/10.1111/1574-6968.12615 Chauhan, A., Bharti, P. K., Goyal, P., Varma, A., \& Jindal, T. (2015) Psychrophilic pseudomonas in antarctic freshwater lake at stornes peninsula, larsemann hills over east Antarctica. SpringerPlus, 4(1) http://doi.org/10.1186/s40064-015-1354-3

Cheriet, T., Mancini, I., Seghiri, R., Benayache, F., Benayache, S. (2015) Chemical constituents and biological activities of the genus Linaria (Scrophulariaceae). Nat. Prod. Res., 29(17), 1589-613. http://doi.org/10.1080/14786419.2014.999243

Cioch, M., Satora, P., Skotniczny, M., Semik-Szczurak, D., \& Tarko, T. (2017) Characterisation of antimicrobial properties of extracts of selected medicinal plants. Polish Journal of Microbiology, 66(4), 463-472. http://doi.org/10.5604/01.3001.0010.7002 
CLSI. (2015). Performance standards for antimicrobial susceptibility testing; twenty-fifth informational supplement. CLSI document M100-S25. Wayne, PA: Clinical and Laboratory Standards Institute.

Costa-Lotufo, L. V., Khan, M. T., Ather, A., Wilke, D. V., Jimenez, P. C. Pessoa, C., Moraes, M. E. A., \& Moraes, M. O. (2005). Studies of the anticancer potential of plants used in Bangladeshi folk medicine. Journal of Ethnopharmacology, 99(1), 21-30. http://doi.org/10.1016/j.jep.2005.01.041

Cowan, M. M. (1999). Plant products as antimicrobial agents. Clinical Microbiology Reviews, 12(4), 564-582.

Davidson, P.M., Bozkurt Cekmer, H., Monu, E.A., Techathuvanan C. (2015) Handbook of Natural Antimicrobials for Food Safety and Quality, $442 \mathrm{pp}$. Woodhead Publishing. ISBN 978-1-78242-034-7. https://doi.org/10.1016/C20130-16441-0

Ehsani, A., Alizadeh, O., Hashemi, M., Afshari, A., \& Aminzare, M. (2017) Phytochemical, antioxidant and antibacterial properties of Melissa officinalis and Dracocephalum moldavica essential oils. Veterinary Research Forum, 8(3), 223 229

Farmakopea Polska, 1999. The Polish Farmaceutical Society. Available:http://www.ptfarm.pl/?pid=1\&language=en

Fratamico, P. M., Debroy, C., Liu, Y., Needleman, D. S., Baranzoni, G. M., \& Feng, P. (2016). Advances in molecular serotyping and subtyping of Escherichia coli. Frontiers in Microbiology, 7. http://doi.org/10.3389/fmicb.2016.00644

Ganzera, M., Zhao, J., \& Khan, I. (2002). Hypericum perforatum-Chemica profiling and quantitative results of St. Johns Wort products by an improved high-performance liquid chromatography method. Journal of Pharmaceutical Sciences, 91(3), 623-630. http://doi.org/10.1002/jps.10057

Gaster, B. \& Holroyd, J. (2000). St John's Wort for depression: a systematic review. Archives of internal medicine. 160 (2), 152-6. http://doi.org/10.1001/archinte.160.2.152

Gonuz, A., Dulger, B. \& Kargioglu. M. (2005). The morphological, anatomical properties and antimicrobial activity of endemic Linaria corifolia Desf (Scrophulariaceae) in Turkey. Pakistan Journal of Biological Sciences, 8(2), 220-226. http://doi.org/10.3923/pjbs.2005.220.226

Gul, M., Cali, I. O., Cansaran, A., Idil, O., Kulu, I., \& Celikoglu, U. (2017) Evaluation of phytochemical content, antioxidant, antimicrobial activity and DNA cleavage effect of endemic Linaria corifolia Desf. (Plantaginaceae) Cogent Chemistry, 3(1), 1-14. http://doi.org/10.1080/23312009.2017.1337293

Gunthard, H., \& Pennekamp, A. (1996). Clinical significance of extraintestinal Hafnia alvei isolates from 61 patients and review of the literature. Clinical Infectious Diseases, 22(6), 1040-1045. http://doi.org/10.1093/clinids/22.6.1040

Hans, D. R. (1998). Chemistry and biology of Hypericum perforatum (St. John's Wort). ACS Symposium Series, 691, 287-298. http://doi.org/10.1021/bk-1998 0691.ch020

Hernández-Saavedra, D., Pérez-Ramírez, I. F., Ramos-Gómez, M., MendozaDíaz, S., Loarca-Piña, G., \& Reynoso-Camacho, R. (2015). Phytochemica characterization and effect of Calendula officinalis, Hypericum perforatum, and Salvia officinalis infusions on obesity-associated cardiovascular risk. Medicinal Chemistry Research, 25(1), 163-172. http://doi.org/10.1007/s00044-015-1454-1 Horiuchi, K., Shiota, S., Hatano, T., Yoshida, T., Kuroda, T., \& Tsuchiya, T. (2007). Antimicrobial activity of oleanolic acid from Salvia officinalis and related compounds on vancomycin-resistant Enterococci (VRE). Biological \& Pharmaceutical Bulletin, 30(6), 1147-1149. http://doi.org/10.1248/bpb.30.1147

Hosseinihashemi, S. K., Hosseinashrafi, S. K., Goldeh, A. J., \& Salem, M. Z (2015). Antifungal and antioxidant activities of heartwood, bark, and leaf extracts of Robinia pseudoacaciar BioResources, 11(1). http://doi.org/10.15376/biores.11.1.1634-1646

Hua, H., Cheng, M., Li, X., \& Pei, Y. (2002). A new pyrroloquinazoline alkaloid from Linaria vulgaris. Chemical \& Pharmaceutical Bulletin, 50(10), 1393-1394. http://doi.org/10.1248/cpb.50.1393

Igumbor, E. O., Ogbimi, A. O., Agbonlahor, D. E., Obi, C. L. (1993). Evaluation of the pathogenicity and virulence of Yersinia species isolated in Edo and Delta States of Nigeria. East Afr. Med. J. 70(12), 803-6.

Ilyina, T. V., Goryachaya, O. V., Toryanik, E. L., Kulish, I. A. \& Kovaleva A. M. (2016). Antimicrobial activity of the genus Galium L. Pharmacognosy Communications, 6(1), 42-47. http://doi.org/10.5530/pc.2016.1.8

Ivanišová, E., Ondrejovič, M., \& Šilhár, S. (2012). Antioxidant activity of milling fractions of selected cereals. Nova Biotechnologica Et Chimica, 11(1). http://doi.org/10.2478/v10296-012-0005-0

Jamshidi-Kia, F., Lorigooini, Z., \& Amini-Khoei, H. (2018). Medicinal plants: past history and future perspective. Journal of Herbmed Pharmacology, 7(1), 1-7. http://doi.org/10.15171/jhp.2018.01

Kennedy, D. O., Little, W., \& Scholey, A. B. (2004). Attenuation of laboratoryinduced stress in humans after acute administration of Melissa officinalis (Lemon Balm). Psychosomatic Medicine, 66(4), 607-613. http://doi.org/10.1097/01.psy.0000132877.72833.71

Khan, A., Rehman, N., Alkharfy, K. M., \& Gilani, A. (2011). Antidiarrheal and antispasmodic activities of Salvia officinalis are mediated through activation of $\mathrm{K}+$ channels. Bangladesh Journal of Pharmacology, 6(2). http://doi.org/10.3329/bjp.v6i2.9156
Klobb T. 1907. Two new glucosides: linarine and pectolinarine. Compt, Rend. $145,331-334$

Kolesnikova, A.G. (1986). Bactericidal and immunocorrective properties of plant extracts. Zhurnal Mikrobiologii Epidemiologii I Immunobiologii, 3, 75-78

Kozłowska, M., Laudy, A. E., Przybył, J., Ziarno, M. \& Majewska, E. (2015). Chemical composition and antibacterial activity of some medicinal plants from Lamiaceae family. Acta Pol. Pharm., 72(4): 757-767.

Lakić, N., Mimica-Dukić, N., Isak, J., \& Božin, B. (2010). Antioxidant properties of Galium verum L. (Rubiaceae) extracts. Open Life Sciences, 5(3), 331-337. http://doi.org/10.2478/s11535-010-0022-4

Lasik, M., Nowak, J., Stachowiak, B. \& Czarnecki, Z. (2007, April). Evaluation of the antagonistic properties of natural antibacterial substances extracted from herbs. Poster session presented at the $1^{\text {st }}$ International Conference and Trade Fair, Eurobiotech, 54, 10-11. Krakow, Poland.

Latifi, G., Ghannadi, A., \& Minaiyan, M. (2015). Anti-inflammatory effect of volatile oil and hydroalcoholic extract of Rosa damascena Mill. on acetic acidinduced colitis in rats. Research in Pharmaceutical Sciences, 10(6), 514-522.

Lin, S., Ho, M., Yang, Y., Liu, J., Wang, I., Lin, S., \& Huang, C. (2011). Abscess caused by Citrobacter koseri infection: three case reports and a literature review. Internal Medicine, 50(12), 1333-1337. http://doi.org/10.2169/internalmedicine.50.4962

Liu, Y., \& Wang, M. (2008). Botanical drugs: challenges and opportunities. Life Sciences, 82(9-10), 445-449. http://doi.org/10.1016/j.lfs.2007.11.007

López, V., Martín, S., Gómez-Serranillos, M. P., Carretero, M. E., Jäger, A. K. \& Calvo, M. I. (2009). Neuroprotective and neurological properties of Melissa officinalis. Neurochemical Research, 34(11), 1955-1961. http://doi.org/10.1007/s11064-009-9981-0

Mahboubi, A. (2012). Evaluation of antibacterial activity of three Iranian medicinal plants. African Journal of Microbiology Research, 6(9) http://doi.org/10.5897/ajmr11.1281

Maksimović, Z., Milenković, M., Vučićević, D., \& Ristić, M. (2008). Chemical composition and antimicrobial activity of Thymus pannonicus All. (Lamiaceae) essential oil. Open Life Sciences, 3(2). http://doi.org/10.2478/s11535-008-0013-x Marinas, I., Oprea, E., Geana, E., Chifiriuc, C., \& Lazar, V. (2014) Antimicrobial and antioxidant activity of the vegetative and reproductive organ of Robinia pseudoacacia. Journal of the Serbian Chemical Society, 79(11), 1363 1378. http://doi.org/10.2298/jsc140304049m

Maskovic, P., Mladenovic, J., Cvijovic, M., Acamovic-Djokovic, G., Solujic, S., \& Radojkovic, M. (2011). Phenolic content, antioxidant and antifungal activities of acetonic, ethanolic and petroleum ether extracts of Hypericum perforatum $L$ Hemijska Industrija, 65(2), 159-164. http://doi.org/10.2298/hemind100819004m Miltiadous, G., \& Elisaf, M. (2011). Native valve endocarditis due to Micrococcus luteus: A case report and review of the literature. Journal of Medical Case Reports, 5(1). http://doi.org/10.1186/1752-1947-5-251

Murray, C. J., \& Lopez, A. D. (1997). Global mortality, disability, and the contribution of risk factors: Global burden of disease study. The Lancet, 349(9063), 1436-1442. http://doi.org/10.1016/s0140-6736(96)07495-8

Nabavi, S. M., Marchese, A., Izadi, M., Curti, V., Daglia, M., \& Nabavi, S. F. (2015). Plants belonging to the genus Thymus as antibacterial agents: From farm to pharmacy. Food Chemistry, 173, 339-347. http://doi.org/10.1016/j.foodchem.2014.10.0

Nováková, L., Spáčil, Z., Seifrtová, M., Opletal, L., \& Solich, P. (2010). Rapid qualitative and quantitative ultra high performance liquid chromatography method for simultaneous analysis of twenty nine common phenolic compounds $\begin{array}{llll}\text { of various } \quad \text { structures. } & \text { Talanta, } & \text { 80(5), } & \text { 1970-1979. }\end{array}$ http://doi.org/10.1016/j.talanta.2009.10.056

Oddo, L. P., \& Piro, R. (2004). Main European unifloral honeys: Descriptive sheets. Apidologie, 35(Suppl. 1). http://doi.org/10.1051/apido:2004049

Pethes, E., Marczal, G., Kery, A. \& Petho, M. (1974). Flavonoids as biologically active agents and their occurrence in the Scrophulariaceae family. Acta Pharm. Hung., 44, 83-90.Prieto, P., Pineda, M., \& Aguilar, M. (1999). Spectrophotometric quantitation of antioxidant capacity through the formation of a phosphomolybdenum complex: specific application to the determination of vitamin E. Analytical Biochemistry, 269(2), 337-341. http://doi.org/10.1006/abio.1999.4019

Rabbani, M., Etemadifar, Z., Karamifard, F., \& Borhani, M. S. (2015) Assessment of the antimicrobial activity of Melissa officinalis and Lawsonia inermis extracts against some bacterial pathogens. Comparative Clinical Pathology, 25(1), 59-65. http://doi.org/10.1007/s00580-015-2140-x

Radulović, N., Stankov-Jovanović, V., Stojanović, G., Šmelcerović, A., Spiteller, M., \& Asakawa, Y. (2007). Screening of in vitro antimicrobial and antioxidant activity of nine Hypericum species from the Balkans. Food Chemistry, 103(1), 15-21. http://doi.org/10.1016/j.foodchem.2006.05.062

Rami, K., \& Guo, L. Z. (2011). Antimicrobial activity of essential oil of Salvia officinalis L. collected in Syria. African Journal of Biotechnology, 10(42), 83978402. http://doi.org/10.5897/ajb10.2615

Rauf, A., Uddin, G., Ali, M., Ahmad, N., \& Gul, S. (2013). Phytochemical screening and antioxidant activity of Pakistani medicinal plants. Wudpecker Journal of Medicinal Plants. 2. 1-6. 
Rawat, S. (2015). Food spoilage: Microorganisms and their prevention. Asian Journal of Plant Science and Research, 5(4), 47-56

Reichling, J., Weseler, A., \& Saller, R. (2001). A current review of the antimicrobial activity of Hypericum perforatum L. Pharmacopsychiatry, 34(Suppl1), 116-118. http://doi.org/10.1055/s-2001-15514

Roby, M. H., Sarhan, M. A., Selim, K. A., \& Khalel, K. I. (2013). Evaluation of antioxidant activity, total phenols and phenolic compounds in thyme (Thymus vulgaris L.), sage (Salvia officinalis L.), and marjoram (Origanum majorana L.) extracts. Industrial Crops and Products, 43, 827-831. http://doi.org/10.1016/j.indcrop.2012.08.029

Rusalepp, L., Raal, A., Püssa, T., \& Mäeorg, U. (2017). Comparison of chemical composition of Hypericum perforatum and $H$. maculatum in Estonia Biochemical Systematics and Ecology, 73, 41-46. http://doi.org/10.1016/j.bse.2017.06.004

Russo, T. (2003). Medical and economic impact of extraintestinal infections due to Escherichia coli: Focus on an increasingly important endemic problem. Microbes and Infection, 5(5), 449-456. http://doi.org/10.1016/s12864579(03)00049-2

Ryan, K. J., \& Ray, C. G. (2014). Sherris medical microbiology. New York: McGraw-Hill Education/Medical.

Saddiqe, Z., Naeem, I., \& Maimoona, A. (2010). A review of the antibacteria activity of Hypericum perforatum L. Journal of Ethnopharmacology, 131(3), 511-521. http://doi.org/10.1016/j.jep.2010.07.034

Salamon, I. (2014). Medicinal plants of high significance in Slovakia. Medicina Plants - International Journal of Phytomedicines and Related Industries, 6(2), 75. http://doi.org/10.5958/0975-6892.2014.00473.0

Salamon, Ivan. (2015). The cultivation and processing of medicinal plants in Slovakia. In R. Radojević, \& A Dimitrijević (Eds.) Paper presented at The Second International Symposium on Agricultural Engineering, 9-10 October (pp. I-37 - I-42). Belgrade - Zemun, Serbia: Faculty of Agriculture, Department for Agricultural Engineering.

Sánchez-Moreno, C., A Larrauri, J. \& Fulgencio, C. (1998). A procedure to measure the antiradical efficiency of polyphenols. Journal of the Science of Food and Agriculture, 76(2), 270-276. http://doi.org/10.1002/(SICI)10970010(199802)76:2<270::AID-JSFA945>3.0.CO;2-9

Schmidt, M., Scholz, C., Gavril, G., Otto, C., Polednik, C., Roller, J., \& Hagen, R. (2013). Effect of Galium verum aqueous extract on growth, motility and gene expression in drug-sensitive and -resistant laryngeal carcinoma cell lines. $\begin{array}{llll}\text { International Journal of Oncology, 44(3), } & 745-760\end{array}$ http://doi.org/10.3892/ijo.2013.2220

Shuman, E. K., \& Malani, P. N. (2018). Infectious diseases mortality in the United States. Jama, 319(12), 1205. http://doi.org/10.1001/jama.2018.1525

Shynkovenko, I. L., Ilyina, T. V., Goryacha, O. V., Kovalyova, A. M., Osolodchenko, T. M., \& Komisarenko, A. M. (2017). The phytochemical profile and antibacterial activity of fluid extracts of Galium verum L. herb. Visnik Farmaciï, 4(92), 25-28. http://doi.org/10.24959/nphj.17.2189

Singleton, V. L. \& Rossi, J. A. (1965). Colorimetry of total phenolics with phosphomolybdic-phosphotungstic acid reagents. Am J Enol Vitic, 16, 144-158

Smith, J. L., Fratamico, P. M., Gunther, N. W. (2007). Extraintestinal pathogenic Escherichia coli. Foodborne Pathog Dis. 4(2): 134-163. http://doi.org/10.1089/fpd.2007.0087

Sokolowska-Wozniak, A., Szewczyk, K., Nowak, R. (2003). Phenolic acids from the herb of Linaria vulgaris (L.) Mill. Herba Pol. 49(3-4), 161-165

Stuart, J. (2014). Herbal Medicines. Fourth edition. Journal of the Medical Library Association: JMLA, 102(3), 222-223. http://doi.org/10.3163/15365050.102.3.019

Subramoniam, A. (2016). Plants with anti-diabetes mellitus properties. Boca Raton: CRC Press, Taylor \& Francis Group.

The world health report 2002: Reducing risks, promoting healthy life. (2002) Geneva: World Health Organization.

Tong, S. Y. C., Davis, J. S., Eichenberger, E., Holland, T. L., \& Fowler, V. G. (2015). Staphylococcus aureus infections: epidemiology, pathophysiology, clinical manifestations, and management. Clinical Microbiology Reviews, 28(3), 603-661. http://http://doi.org/10.1128/CMR.00134-14

Vlase, L., Mocan, A., Hanganu, D., Benedec, D., Gheldiu, A., \& Crisan, G. (2014). Comparative study of polyphenolic content, antioxidant and antimicrobial activity of four Galium species (Rubiaceae). Digest Journal of Nanomaterials and Biostructures, 9(3), 1085-1094

Vrchovská, V., Spilková, J., Valentão, P., Sousa, C., Andrade, P. B., \& Seabra R. M. (2008). Assessing the antioxidative properties and chemical composition of Linaria vulgaris infusion. Natural Product Research, 22(9), 735-746. http://doi.org/10.1080/14786410601132360

Walch, S. (2011). Antioxidant capacity and polyphenolic composition as quality indicators for aqueous infusions of Salvia officinalis L. (sage tea). Frontiers in Pharmacology, 2. http://doi.org/10.3389/fphar.2011.00079

Willett, W. C. (2002). Balancing life-style and genomics research for disease prevention. Science, 296(5568), 695-698. http://doi.org/10.1126/science.1071055 Zheng, W., \& Wang, S. Y. (2001). Antioxidant activity and phenolic compounds in selected herbs. Journal of Agricultural and Food Chemistry, 49(11), 5165 5170. http://doi.org/10.1021/jf010697n
Zou, Y., Lu, Y. \& Wei, D. (2004). Antioxidant activity of a flavonoid-rich extract of Hypericum perforatum L. in vitro. J. Agric. Food Chem, 52(16), 5032-5039. http://doi.org/10.1021/jf049571r 